\title{
Nutritional Requirements and Metabolism of Mycoplasma laidlawii
}

\author{
By S. RAZIN AND ALICE COHEN \\ Department of Clinical Microbiology, Hebrew University-Hadassah Medical \\ School, Jerusalem, Israel
}

(Received 31 May 1962)

\begin{abstract}
SUMMARY
A study of the nutritional requirements of Mycoplasma laidlawii has led to the development of a growth medium containing inorganic salts, amino acids, glucose, nucleosides, vitamins and $1 \%(\mathrm{w} / \mathrm{v})$ bovine serum albumin fraction V. No cholesterol was detected in this medium. Potassium, magnesium and phosphate ions were essential growth requirements. Sodium chloride provided the high tonicity required by the growth medium. The addition of an ammonium salt to the medium enabled the growth of the test organism in the presence of 13 amino acids. Resting organisms of $M$. laidlawi $i$ did not catabolize any of the 22 different amino acids tested under conditions which allowed amino acid degradation by Mycoplasma hominis. Glucose was essential for growth and could be replaced by maltose but not galactose, fructose, mannose, lactose or sucrose. The requirement for nucleic acid precursors was satisfied by adenosine, guanosine and cytidine, and that for vitamins by nicotinic acid, riboflavin, folinic acid, pyridoxine, pyridoxal and thiamine. Cholesterol was not necessary for growth of the test organism.
\end{abstract}

\section{INTRODUCTION}

The nutritional requirements of the Mycoplasmataceae are of special interest since they are the smallest autonomous self-replicating organisms known. Our knowledge concerning the nutritional requirements of this group is still fragmentary and based on experiments performed with partially defined media (Adler \& Shifrine, 1960; Razin, $1962 a$ ). An attempt to compound a chemically defined culture medium for Mycoplasma was made by Razin \& Knight (1960a) with the saprophytic Mycoplasma laidlawii as the main test organism. The medium obtained was only partially defined, but enabled the determination of nucleic acid precursor requirements of the saprophytic Mycoplasma (Razin \& Knight, 1960b; Razin, 1962b). The aim of the present work was to render the partially defined medium of Razin \& Knight $(1960 a)$ as chemically defined as possible. Various modifications of this medium led to the development of a 'minimal' medium, which enabled the determination of inorganic ion, carbohydrate, amino acid, nucleic acid precursor and vitamin requirements of $M$. laidlawii. In order to relate the observed nutritional requirements to metabolic activity, the amino acid metabolism of $\boldsymbol{M}$. laidlawii was also investigated.

The 'minimal' medium obtained proved to be cholesterol-free and was thus suitable for ascertaining the cholesterol requirement. The problem of cholesterol 
requirement by saprophytic Mycoplasma is of great theoretical interest. The parasitic Mycoplasma have been shown to require cholesterol or related sterols for growth (Edward \& Fitzgerald, 1951; Smith \& Lynn, 1958; Rodwell, 1956). As hitherto no other group of bacteria is known to require cholesterol, it was suggested to use this requirement as a criterion for distinguishing Mycoplasma spp. from bacteria and L-forms (Edward \& Freundt, 1956). The possibility that the saprophytic Mycoplasma do not require cholesterol was already indicated by several authors (Razin \& Knight, 1960 $a$; Rothblat \& Smith, 1961). Growth of M. laidlazoii in the 'minimal' medium has proved that this saprophytic strain does not require cholesterol for growth.

\section{METHODS}

Organisms. Mycoplasma laidlawii strain A (PG 8) was kindly provided by Dr D. G. ff. Edward (The Wellcome Research Laboratories, Beckenham, Kent); in the sequel 'Mycoplasma laidlawii' will refer to this strain. Mycoplasma hominis strain no. 23 was isolated in our laboratory from a case of vaginitis.

Media. A modified Edward medium (Razin \& Oliver, 1961) was used for keeping stock cultures and growing the organism used in the nutrition and metabolic experiments. The same medium, solidified with $1.25 \%$ (w/v) Bacto-agar (Difco, certified) was used for viable counts (Butler \& Knight, 1960). The partially defined medium described by Razin \& Knight (1960a) and Razin (1962 b) served as a basis for the nutritional studies. This medium will be referred to as the partially defined medium.

Pyrex glassware was used in all experiments. Before use it was cleaned in a chromic + sulphuric acid mixture and thoroughly rinsed in distilled water. The tested medium was dispensed in $10 \mathrm{ml}$. quantities into $6 \times \frac{5}{8}$ in. sterile screw-capped test tubes. Sterilization of heat-labile substances was carried out by suction through sintered glass filters or by steaming for 20 min. (Merrifield \& Dunn, 1950).

Conditions of groroth. The organisms were grown in $5 \mathrm{ml}$. liquid Edward medium for $24 \mathrm{hr}$. at $37^{\circ}$, harvested and washed according to Butler \& Knight (1960). Each tube of experimental medium received $0.1 \mathrm{ml}$. of a $1 / 10$ dilution of the washed organisms. The initial inoculum contained about $10^{5}$ viable particles $/ \mathrm{ml}$. medium. Inoculated test tubes were incubated statically in air at $37^{\circ}$. Growth was usually estimated after incubation for $96 \mathrm{hr}$.

Assessment of growth. Growth in experimental media was measured by titration of the acid formed by the organisms during growth (Razin \& Knight, 1960a) or by the viable count technique as described by Butler \& Knight (1960).

Suspensions of organisms. The organisms were grown in 1-21. quantities of liquid Edward medium in gently rotated Erlenmeyer flasks. Mycoplasma laidlawii was harvested after $24 \mathrm{hr}$. and the slower growing $M$. hominis after $48 \mathrm{hr}$. of incubation at $37^{\circ}$. The organisms were sedimented by centrifugation at $9000 \mathrm{~g}$ for $10 \mathrm{~min}$. at $6^{\circ}$ and resuspended in $0.067 \mathrm{M}$-phosphate buffer $(\mathrm{pH} 7 \cdot 8)$. Since washing with buffer decreased the metabolic activity of the organisms very markedly, they were used unwashed. Suspensions of the organism in buffer were made to contain $1 \mathrm{mg}$. $\mathrm{N} / \mathrm{ml}$. Cellular- $\mathrm{N}$ was determined by comparing turbidity at $420 \mathrm{~m} \mu$ to a previously prepared standard curve which related turbidity and cellular- $\mathbf{N}$ as determined by the micro-Kjeldahl procedure (Ma \& Zuazaga, 1942).

Cell-free extract. A very thick suspension of Mycoplasma laidlawii was crushed 
without abrasives in a Hughes press previously cooled to $-\mathbf{3 5}^{\circ}$ (Hughes, 1951). The intact organisms and debris were sedimented by centrifugation at $10,000 \mathrm{~g}$ for $20 \mathrm{~min}$. The resulting supernatant fluid was opalescent.

Chemicals. Most of the chemicals used were analytical reagents. Crystallized bovine plasma albumin was the product of Armour Pharmaceutical Co. (Kankakee, Illinois, U.S.A.). Albumin (bovine) powder fraction $\mathrm{V}$ was obtained from the Mann Research Laboratories Inc. (New York 6, N.Y., U.S.A.). Defatted albumin fraction $V$ was prepared by extraction of the dry powder with methanol and ether (Gilby, Few \& McQuillen, 1958). Dialysis of human serum and albumin fraction V was carried out as described previously (Razin \& Knight, 1960a). Dialysis was improved by constant stirring of the dialysing medium. The dialysed serum and albumin solutions were sterilized by filtration through sintered glass filters. The dialysed serum was kept at $-10^{\circ}$ until used.

Manometric methods. Oxygen uptake was measured by the conventional Warburg manometric technique (Umbreit, Burris \& Stauffer, 1957). Each Warburg vessel contained $10 \mu$ mole substrate, $1 \mathrm{ml}$. cell suspension (equiv. $1 \mathrm{mg}$. $\mathrm{N}$ ), $1 \mathrm{ml}$. of $0.067 \mathrm{M}$-phosphate buffer ( $\mathrm{pH} \mathrm{7.8)}$ and $0.1 \mathrm{ml}$. of $1 \times 10^{-4} \mathrm{M}$-pyridoxal phosphate; the total volume was $3.2 \mathrm{ml}$; $0.2 \mathrm{ml}$. of $15 \%(\mathrm{w} / \mathrm{v}) \mathrm{KOH}$ was in the centre well. Incubation was carried out in air at $30^{\circ}$ for $3 \mathrm{hr}$. All manometric data were corrected for the endogenous rates.

Transamination. This was tested in Thunberg tubes with hydrogen as the gas phase. Each tube contained $0.5 \mathrm{ml}$. of cell-free extract, $0.2 \mathrm{ml}$. of $0.067 \mathrm{M}$-phosphate buffer ( $\mathrm{pH} \mathrm{7.8),} 10 \mu$ mole sodium pyruvate, $10 \mu$ mole glutamic acid or aspartic acid and $0.01 \mu$ mole pyridoxal phosphate; total volume $1.2 \mathrm{ml}$. Incubation was carried out at $37^{\circ}$ for $3 \mathrm{hr}$.

Determination of amino acids. Paper chromatography was used for qualitative and quantitative determinations of amino acids and their degradation products (Giri, Radhakrishnan \& Vaidyanathan, 1952). The standard solvent was butanol + acetic acid + water $(40+10+50$, by vol. $)$. The papers were sprayed with $0 \cdot 5 \%(w / v)$ ninhydrin in acetone. Proline was identified by spraying the paper with $0.2 \%(w / v)$ isatin in acetone (Block, Durrum \& Zweig, 1958). For the identification of citrulline the paper was sprayed with $1 \%(\mathrm{w} / \mathrm{v}) p$-dimethylaminebenzaldehyde in $\mathrm{N}-\mathrm{HCl}$ (Block et al. 1958).

Ammonia production was estimated by nesslerization (Umbreit, Burris \& Stauffer, 1957).

Total cholesterol. Fifty ml. of the minimal medium (Table 2) were freeze-dried. The lipid of the resulting solid residue was extracted by methanol and ether (Gilby et al. 1958). The etheral extract was saponified to liberate esterified cholesterol and the total cholesterol determined by digitonin precipitation and the LiebermannBurchard test, as outlined by Cook (1958).

\section{RESULTS}

\section{Inorganic ion requirements}

The phosphate buffer included in the partially defined medium of Razin \& Knight (1960a, Table 1 ) has a low buffering capacity at $\mathrm{pH}$ values near $8 \cdot 0$, which is the optimal pH for growth of Mycoplasma laidlawii (Razin \& Oliver, 1961) and becomes 
growth-inhibitory at concentrations higher than 0.04M (Razin \& Knight, 1960a). 2-Amino-2-hydroxymethylpropane-1:3-diol (tris) buffer, with optimal buffering capacity at pH 8.0, was therefore tried as a substitute for phosphate buffer. Figure 1 shows that growth of $M$. laidlawii was markedly improved both in the rate and in the total growth when phosphate buffer was replaced by tris buffer. The optimal concentration of tris buffer for growth was found to be $0.05 \mathrm{M}$. Tris buffer was used instead of phosphate buffer in all subsequent experiments.

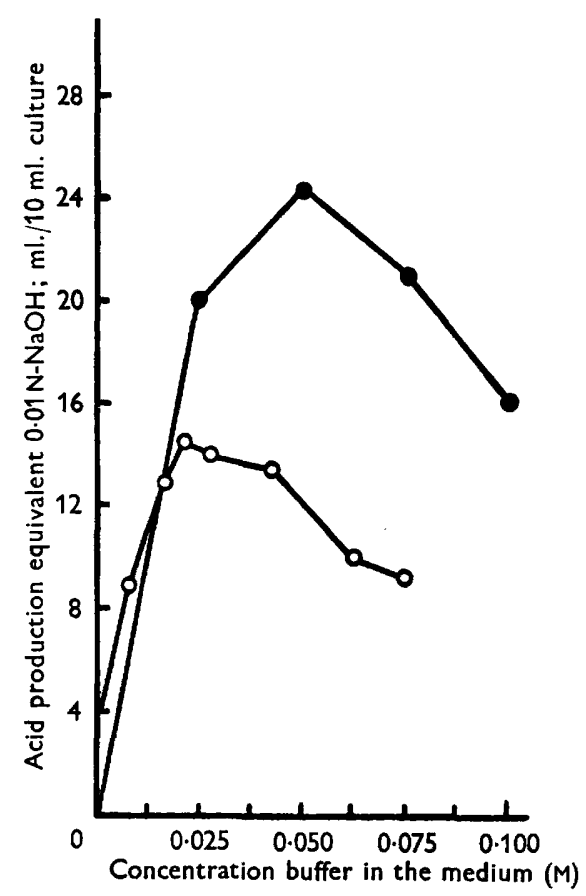

Fig. 1

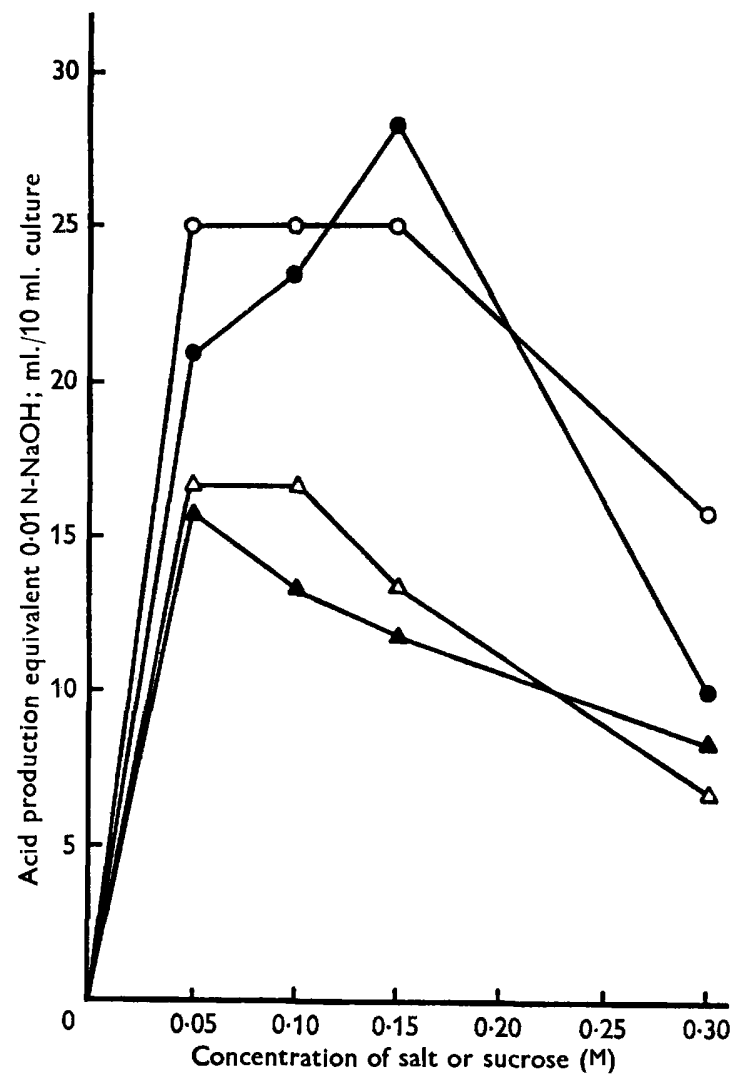

Fig. 2

Fig. 1. Growth of Mycoplasma laidlawii in partially defined medium containing $10 \%(\mathrm{v} / \mathrm{v})$ human serum and different amounts of phosphate buffer $(O)$ or tris buffer $(0)$ at pH 8.3.

Fig. 2. Effects of: sodium chloride $(\odot)$; sodium acetate $(0)$; sodium lactate $(\triangle)$; sucrose ( $\Delta$ ); on the growth of Mycoplasma laidlareii in partially defined medium from which sodium chloride was omitted. The medium contained $10 \%(v / v)$ human serum and salt-free Bacto-vitamin free Casamino acids.

The role of sodium chloride included in the partially defined medium was tested by its omission from the growth medium. For this experiment the Bacto-vitamin

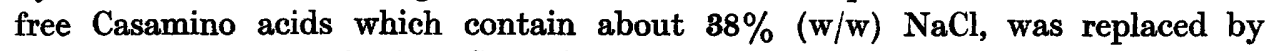
salt-free Bacto-vitamin free Casamino acids. As seen from Fig. 2, no growth of the test organism took place when $\mathrm{NaCl}$ was omitted. Optimal growth was obtained 
with $0 \cdot 15 \mathrm{M}-\mathrm{NaCl}$. Sodium acetate, and to a less extent sodium lactate and sucrose, may replace $\mathrm{NaCl}$ in the growth medium (Fig. 2). Spermine, which is known to protect fragile organisms and organelles from lysis in hypotonic media (Tabor, Tabor \& Rosenthal, 1961) could not replace $\mathrm{NaCl}$ in the medium. Spermine became growth-inhibitory at concentrations of $10 \mu \mathrm{g} . / \mathrm{ml}$. or higher.

No growth of the test organism occurred when $\mathrm{KCl}$ was omitted from the growth medium (Fig. 3). Mycoplasma laidlawii did not grow when magnesium sulphate or

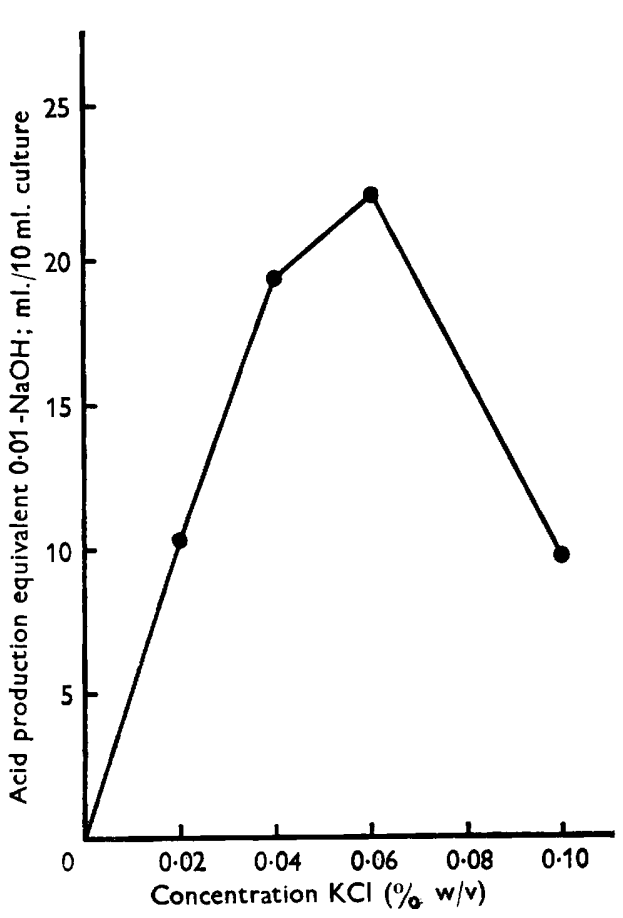

Fig. 3

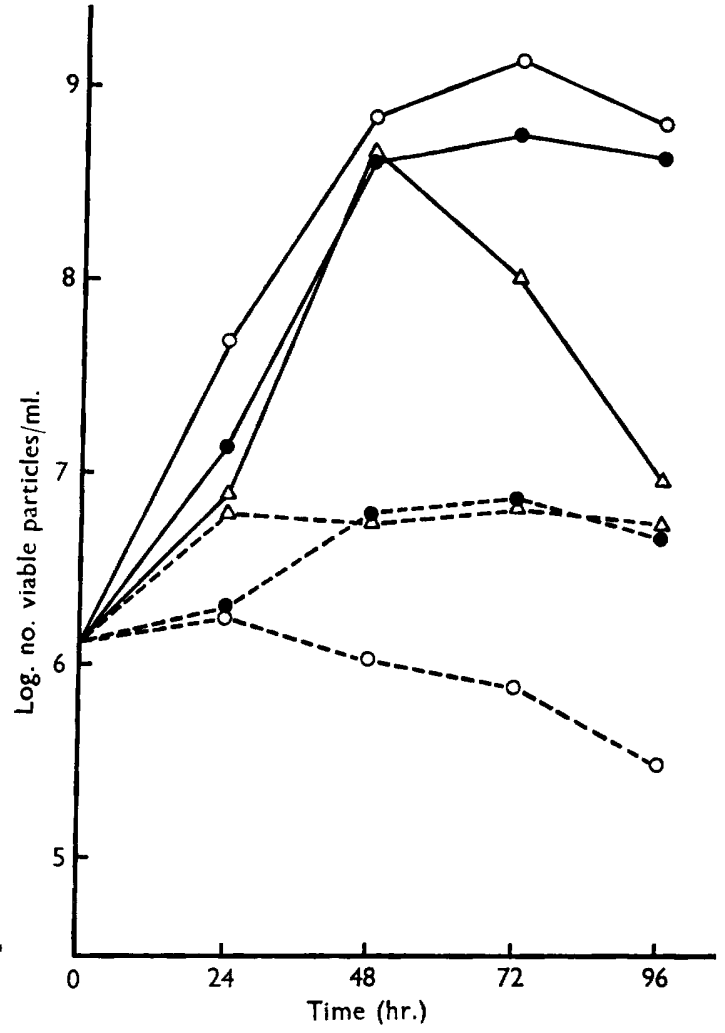

Fig. 4

Fig. 3. The growth of Mycoplasma laidlawii in partially defined medium containing different amounts of potassium chloride $+10 \%(v / v)$ human serum.

Fig. 4. Requirement of glucose for growth of Mycoplasma laidlawii. The partially defined medium contained: $10 \%(v / v)$ whole human serum (०); equiv. $10 \%(v / v)$ human serum dialysed $(O) ; 1 \%(w / v)$ bovine serum albumin fraction $\mathbf{V}(\triangle)$. -; with $0.75 \%(w / v)$ glucose. - - , without glucose.

sodium phosphate were omitted from the minimal medium (Table 2). Addition to the minimal medium of several inorganic salts known to be required by microorganisms in trace amounts failed to improve growth. The salts tested were:

$$
\begin{gathered}
\mathrm{Fe}\left(\mathrm{NH}_{4}\right)_{2}\left(\mathrm{SO}_{4}\right)_{2} .6 \mathrm{H}_{2} \mathrm{O} ; \mathrm{MnSO}_{4} .4 \mathrm{H}_{2} \mathrm{O} ; \mathrm{ZnSO}_{4} .7 \mathrm{H}_{2} \mathrm{O} ; \\
\mathrm{CuSO}_{4} .5 \mathrm{H}_{2} \mathrm{O} ;\left(\mathrm{NH}_{4}\right)_{6} \mathrm{Mo}_{7} \mathrm{O}_{24} \cdot 4 \mathrm{H}_{2} \mathrm{O} ; \mathrm{H}_{3} \mathrm{BO}_{3} .
\end{gathered}
$$

Growth of $M$. laidlazvii was inhibited by $\mathrm{Fe}\left(\mathrm{NH}_{4}\right)_{2}\left(\mathrm{SO}_{4}\right)_{2} \cdot 6 \mathrm{H}_{2} \mathrm{O}$ at concentrations of $10 \mu \mathrm{g} . / \mathrm{ml}$. or higher. 


\section{Carbohydrate requirement}

Glucose was essential for the growth of Mycoplasma laidlawii in all the experimental media used in the present work (Fig. 4). The requirement for glucose, when tested in the albumin-containing medium, could be completely replaced by maltose, but not by galactose, fructose, mannose, lactose or sucrose.

\section{Amino acid requirements}

Casamino acids served as the main source of amino acids in the partially defined medium of Razin \& Knight (1960a). Small amounts of amino acids were also supplied by the serum component of the medium. To eliminate the latter source of free amino acids, the serum was thoroughly dialysed. Dialysis did not affect to any significant degree the growth-promoting activity of the serum. Replacement of Casamino acids by known amino acid mixtures was then tried with the partially defined medium, which contained $10 \%(\mathrm{v} / \mathrm{v})$ dialysed human serum. Thirteen different amino acid mixtures were tested. Twelve mixtures were compounded according to various authors who had used them in defined media for tissue cultures or microorganisms. One amino acid mixture was compounded according to an analysis of Casamino acids kindly provided by Difco Laboratories. Several of the tested amino acid mixtures enabled good growth of the test organism, but none equalled Casamino acids.

The mixture which provided best growth was then chosen for the analysis of the amino acid requirements. By a single omission technique, cystine and isoleucine were found to be essential for the growth of Mycoplasma laidlawii. Amino acids were now added one by one to cystine and isoleucine, and the resulting mixtures tested for their effect on the growth of $\boldsymbol{M}$. laidlawii. Good growth could be obtained only with mixtures containing at least 15 amino acids. As most of these amino acids were interchangeable, it was suggested that mixtures containing a small number of amino acids were unable to promote growth not only because of the lack of essential amino acids, but also because of an insufficient amount of nitrogen in the medium. The effect of the addition of an ammonium salt was therefore tested. Ammonium sulphate or ammonium chloride markedly improved growth when incorporated into media containing various amino acid mixtures (Fig. 5). Potassium nitrate had no such effect.

The addition to the dialysed serum medium of $\left(\mathrm{NH}_{4}\right)_{2} \mathrm{SO}_{4}$ together with a mixture of 11 amino acids (the first eleven mentioned in Table 2) enabled good growth of Mycoplasma laidlawii equivalent to that obtained with Casamino acids (Fig. 6). Of the eleven amino acids included in this medium only cystine, isoleucine, glutamine and asparagine were shown to be definite growth requirements. The omission of any one of these 4 amino acids abolished or markedly decreased growth, whereas the omission of any of the other 7 affected growth slightly or not at all. However, growth in the presence of all 11 amino acids was always better than in the presence of cystine + isoleucine + glutamine + asparagine only.

No growth of Mycoplasma laidlawii took place with the above mentioned amino acid mixture when the dialysed serum was replaced by crystalline bovine plasma albumin or bovine serum albumin fraction V (Fig. 6). Growth appeared when 
methionine was added, and was further improved by the addition of threonine. As seen in Fig. 6, growth of $M$. laidlawii in the medium containing a mixture of thirteen amino acids and $1 \%(\mathrm{w} / \mathrm{v})$ bovine serum albumin fraction $\mathrm{V}$ was equal to that obtained with Casamino acids + dialysed serum. Experiments were carried out with a view to replacing the methionine required for growth of $M$. laidlawii in the albumin medium. The addition to the medium of homocysteine together with ' $\mathrm{C}_{1}$ unit' donors, such as glycine, serine, formate or choline, with folinic acid and vitamin $B_{12}$ as co-factors, did not enable growth when methionine was omitted.

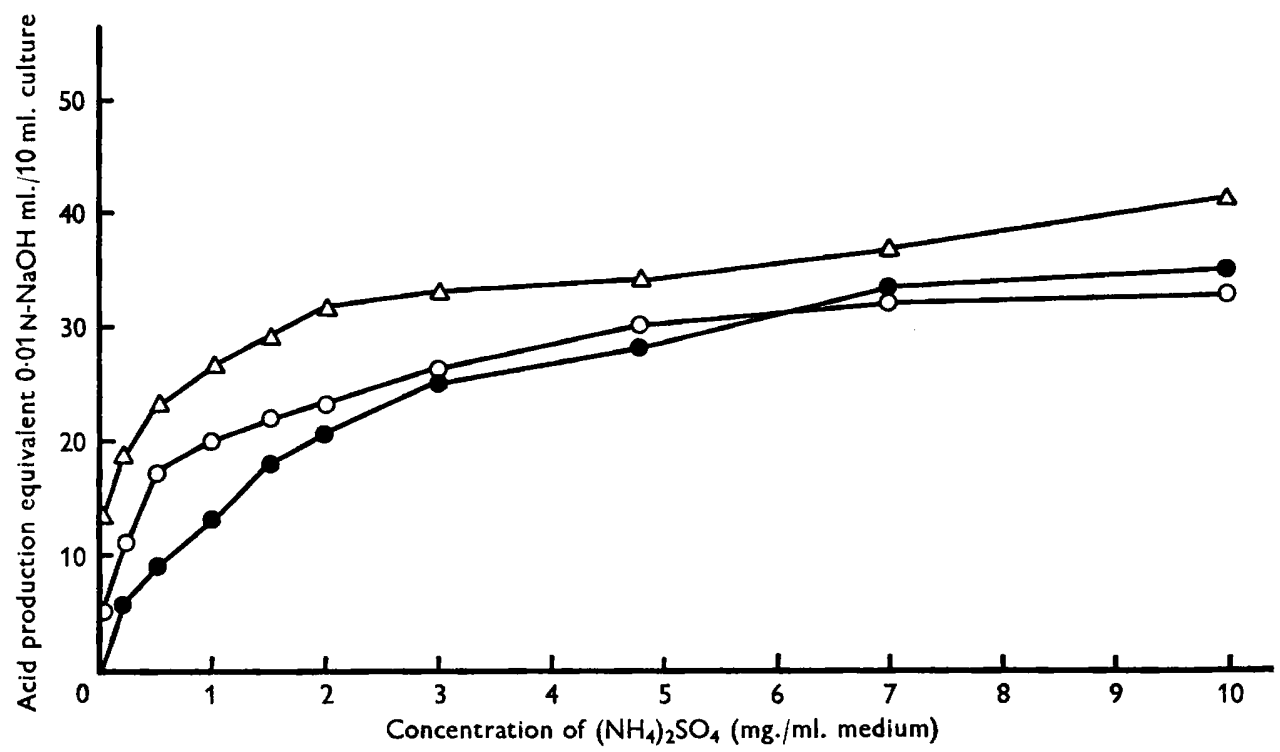

Fig. 5. The effect of ammonium sulphate on the growth of Mycoplasma laidlawii. The partially defined medium contained $10 \%(\mathrm{v} / \mathrm{v})$ dialysed human serum and 10 amino acids (the first ten mentioned in Table 2 ; $)$ ); 15 amino acids (glycine, DL-leucine, L-tyrosine, L-histidine, L-arginine, DL-valine, DL-isoleucine, L-tryptophan, DL-phenylalanine, DL-aspartic acid, L-lysine, L-glutamic acid, DL-methionine, L-cystine, DLthreonine; O); 21 amino acids (the previous mixture $+\mathrm{L}$-hydroxyproline, DL-serine, L-cysteine, DL-alanine, L-glutamine, L-asparagine; $\Delta$ ).

\section{Amino acid metabolism}

To establish the most suitable conditions for testing amino acid metabolism of non-multiplying suspensions of Mycoplasma laidlawii manometric experiments with glucose as substrate were made. Glucose is known to be oxidized by $\boldsymbol{M}$. laidlawii (Tourtellotte \& Jacobs, 1960; Neimark \& Pickett, 1960). It was found that even one washing of the organisms with 0.067 M-phosphate buffer ( $\mathrm{pH} \mathrm{7 \cdot 6)}$ markedly decreased their oxidative activity, while a second washing abolished it completely. As the endogenous oxygen uptake by unwashed organisms was very low, unwashed organisms were used for all subsequent experiments. The $\mathrm{pH}$ value of the phosphate buffer used in the reaction vessels had a marked influence on glucose oxidation by the suspensions. No oxygen uptake was noted at $\mathrm{pH} 6 \cdot 0$, low values were obtained at $\mathrm{pH} 7 \cdot 0$ and the highest values at $\mathrm{pH} 7 \cdot 8$ to $8 \cdot 4$. Consequently $0.067 \mathrm{M}$-phosphate buffer ( $\mathrm{pH} 7 \cdot 8$ ) was chosen for the following experiments. 
Twenty-two amino acids (glycine, DL-alanine, DL-leucine, DL-isoleucine, Ltyrosine, DL-phenylalanine, L-tryptophan, L-proline, L-hydroxyproline, L-histidine, L-arginine, DL-serine, DL-valine, DL-aspartic acid, L-asparagine, L-glutamic acid, L-glutamine, L-lysine, DL-methionine, L-cystine, L-cysteine, DL-threonine) were tested for oxidation and degradation by suspensions of $M$. laidlawii. In repeated experiments no significant oxygen uptake, substrate disappearance, or ammonia production was observed with any of these amino acids. Experiments were also made with strict adherence to the procedure described by Smith (1955) for demonstrating amino acid degradation by Mycoplasma hominis. The results of these experiments, carried out under aerobic and under anaerobic conditions and in the

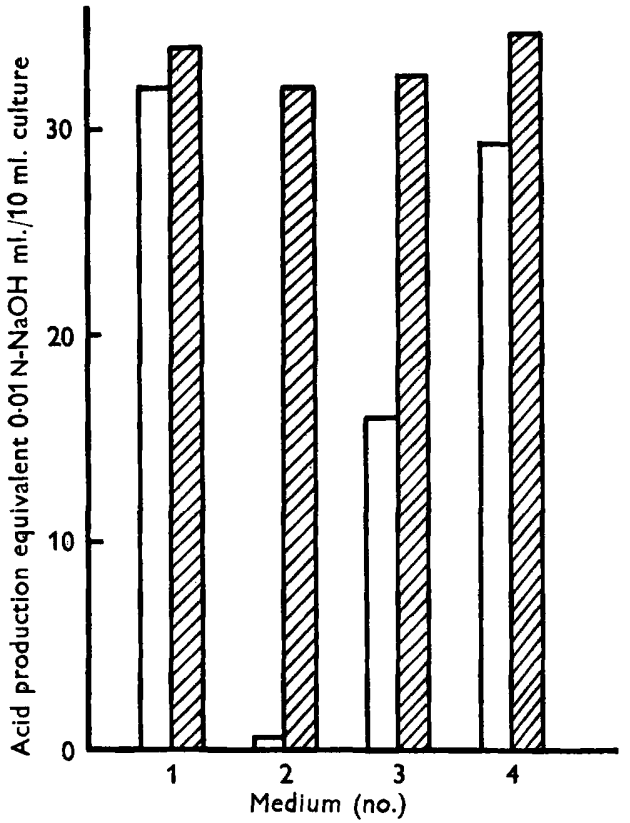

Fig. 6

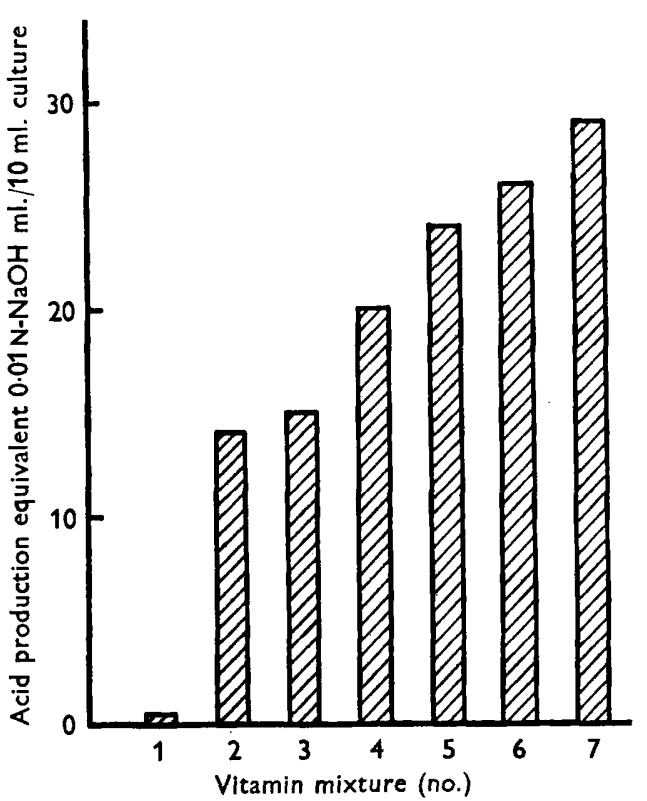

Fig. 7

Fig. 6. Growth of Mycoplasma laidlawii with Casamino acids or known amino acid mixtures. The partially defined medium contained $0.7 \%(\mathrm{w} / \mathrm{v})\left(\mathrm{NH}_{4}\right)_{2} \mathrm{SO}_{4}+10 \%(\mathrm{v} / \mathrm{v})$ dialysed serum or $1 \%(\mathrm{w} / \mathrm{v})$ bovine serum albumin fraction $\mathrm{V}+$ : (1) Casamino acids; (2) 11 amino acids (the first acids mentioned in Table 2); (3) the same as (2) $+0.2 \mathrm{mg}$. DL-methionine $/ \mathrm{ml}$; (4) the same as (3)+0.4 mg. DL-threonine $/ \mathrm{ml}$. $\square$, bovine serum albumin $(1 \% \mathrm{w} / \mathrm{v}) ; \mathbb{Z}$, dialysed human $\operatorname{serum}(10 \% \mathrm{w} / \mathrm{v})$.

Fig. 7. Growth of Mycoplasma laidlawii with various vitamin mixtures. The minimal medium (Table 2) contained: (1) riboflavin alone; (2) riboflavin + nicotinic acid; (3) as (2) + folinic acid; (4) as (3) + pyridoxine $\mathrm{HCl}$; (5) as (4) + pyridoxal $\mathrm{HCl}$; (6) as (5) + thiamine; (7) as (6) + nicotinamide, pantothenic acid (Ca salt), folic acid, choline-HCl, $m$-inositol. The final concentration of each vitamin was $2.5 \mu \mathrm{g} . / \mathrm{ml}$. medium, except folinic acid which was $1 \mu \mathrm{g} . / \mathrm{ml}$. medium.

presence of $10^{-5} \mathrm{M}$-pyridoxal phosphate were likewise negative. The addition of $5 \mu$ mole glucose to each of the reaction vessels did not promote degradation of any of the amino acids tested. A single experiment to test transaminase activity in a cell-free extract of $\boldsymbol{M}$. laidlawii also gave negative results. 
To make sure that our experimental conditions were suitable for amino acid degradation by Mycoplasma organisms a simultaneous experiment was carried out with Mycoplasma laidlawii and M. hominis, the latter having been found by Smith (1960) to degrade several amino acids. The following amino acids were tested: Larginine, L-glutamine, L-glutamic acid, DL-aspartic acid, L-alanine. M. laidlawii did not attack any of these substrates, whereas $\boldsymbol{M}$. hominis degraded arginine completely to citrulline and ornithine, and glutamine to glutamic acid (Table 1). This degradation was not accompanied by any significant oxygen uptake. The three other amino acids tested were not attacked by $M$. hominis.

\title{
Table 1. Degradation of arginine and glutamine by resting Mycoplasma hominis organisms
}

\begin{abstract}
Each Warburg vessel contained $10 \mu$ mole substrate, $1 \mathrm{ml}$. cell suspension (equiv. $1 \mathrm{mg}$. N), $1 \mathrm{ml} .0 \cdot 067 \mathrm{M}$-phosphate buffer (pH 7.8) 0.1 ml. $1 \times 10^{-4} \mathrm{M}$-pyridoxal phosphate; total vol. $3.2 \mathrm{ml}$. In the centre well was $0.2 \mathrm{ml}$. of $15 \%(\mathrm{w} / \mathrm{v}) \mathrm{KOH}$. Incubation was in air at $30^{\circ}$ for $3 \mathrm{hr}$. The amount of substrates and degradation products was determined chromatographically at the end of the incubation period.
\end{abstract}

\begin{tabular}{|c|c|c|c|c|c|}
\hline \multirow[t]{2}{*}{ Substrate } & \multicolumn{5}{|c|}{$\begin{array}{c}\text { Amount of substrate and degradation products at the end of } \\
\text { the incubation period ( } \mu \text { mole) }\end{array}$} \\
\hline & Arginine & Citrulline & Ornithine & Glutamine & $\begin{array}{l}\text { Glutamic } \\
\text { acid }\end{array}$ \\
\hline L-Arginine & $\mathbf{0}$ & 0.75 & $9 \cdot 0$ & - & - \\
\hline L-Glutamine & - & - & - & $5 \cdot 4$ & $4 \cdot 1$ \\
\hline
\end{tabular}

Vitamin requirements

The requirements of Mycoplasma laidlawii for nicotinic acid, riboflavin, folinic acid and pyridoxine or pyridoxal could be demonstrated in all the experimental media tested. In some experiments the omission of thiamine from the growth medium decreased growth to some extent. A mixture of the above mentioned six vitamins enabled growth of $M$. laidlawii comparable with that obtained with the full mixture of ten vitamins included in the partially defined medium (Fig. 7).

Nicotinamide, diphosphopyridine nucleotide or triphosphopyridine nucleotide were much less effective in growth-promotion than nicotinic acid, whereas flavinadenine dinucleotide, pyridoxal phosphate and thiamine pyrophosphate were fully capable of replacing the entire requirement for the corresponding parent vitamins. The addition to the minimal medium (Table 2 ) of various vitamins and growth factors, such as vitamin $B_{12}$, biotin, $p$-aminobenzoic acid, thioctic acid or putrescine, did not improve the growth of $\boldsymbol{M}$. laidlarvii.

\section{The minimal medium}

The determination of inorganic ion, amino acid, carbohydrate, vitamin, nucleic acid precursor (Razin, 1962b) and albumin requirements, permitted the composition of a minimal medium, suitable for growth of Mycoplasma laidlawii. The ingredients of this medium are presented in Table 2. The extent of growth of the test organism in this minimal medium was comparable to that obtained in earlier serum-containing media (Fig. 8). The minimal medium was also found suitable for serial transfers of M. laidlawii. More than ten transfers were made in this medium without any reduction in growth. Sodium acetate, sodium lactate, glycerol and potassium 
citrate have been reported to promote growth of various Mycoplasma organisms (Smith \& Lynn, 1958; Rodwell \& Abbot, 1961; Dr M. Shifrine, personal communication). These substances did not improve growth of $M$. laidlawii when added in various concentrations and mixtures to the minimal medium; lactate and citrate inhibited growth at concentrations higher than $0.5 \mathrm{mg} . / \mathrm{ml}$. The development of the minimal medium enabled a more direct approach to the examination of the cholesterol requirement of saprophytic Mycoplasma; no cholesterol was detected in this medium. Lipid extraction or dialysis of the serum albumin included in the medium did not affect growth of $M$. laidlawii. Cholesterol, when added to the minimal medium, did not improve growth.

Table 2. The ingredients of the minimal medium for Mycoplasma laidlawii

Inorganic salts (g./l.)
$\mathrm{NaCl}$
$\left(\mathrm{NH}_{4}\right)_{2} \mathrm{SO}_{4}$
2-Amino-2-hydroxymethylpro-
pane-1:3-diol ('tris')
KCl
$\mathrm{MgSO}_{4} .7 \mathrm{H}_{2} \mathrm{O}$
$\mathrm{Na}_{2} \mathrm{HPO}_{4}$
Vitamins (mg./l.)
Nicotinic acid
Riboflavin
Folinic acid
Pyridoxine-HCl
Pyridoxal-HCl
Thiamine
Nucleosides (mg./l.)
Adenosine
Guanosine
Cytidine

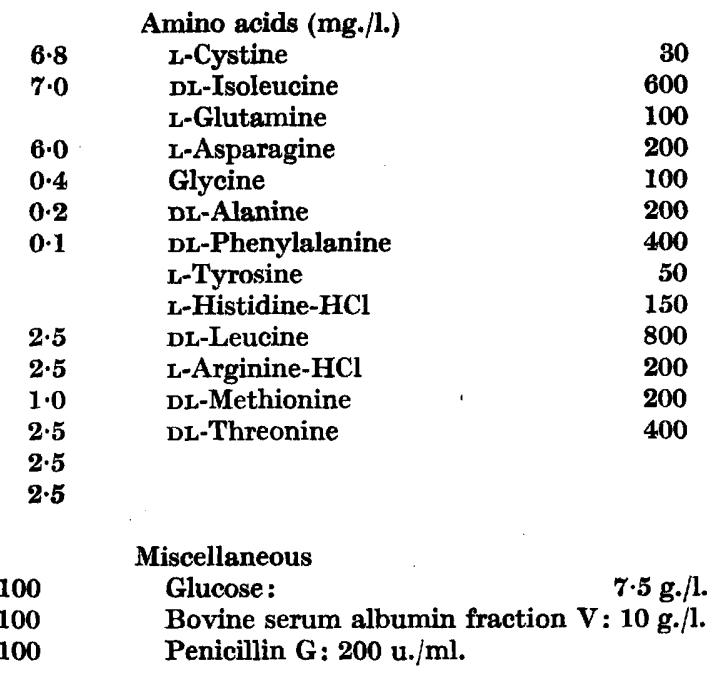

Medium finally adjusted to $\mathrm{pH} 8 \cdot 3$

\section{Groroth curves of Mycoplasma laidlawii in the experimental media}

In most of the experiments described so far growth was measured indirectly by the titration of acid formed by the organisms during growth. Experiments with the viable count technique were therefore made to study more directly the rate and extent of growth of Mycoplasma laidlawii in the experimental media used. The growth curves presented in Fig. 8 show that growth obtained with the partially defined medium, containing either whole or dialysed serum, was comparable to that obtained in the complex Edward medium. Replacement of the serum by serum albumin fraction $\mathrm{V}$ or by crystallized albumin decreased growth to some extent. Replacement of the serum component by activated charcoal did not promote growth, but the inoculum survived for about $48 \mathrm{hr}$. and then decreased. BactoPPLO serum fraction (Smith \& Morton, 1951) was much inferior to serum when tested in the partially defined medium. No growth of $M$. laidlawii took place in this medium when it contained less than $3 \%(v / v)$ of Bacto-PPLO serum fraction; growth with $10 \%(\mathrm{v} / \mathrm{v})$ Bacto-PPLO serum fraction was still less to that obtained with serum (Fig. 8). 


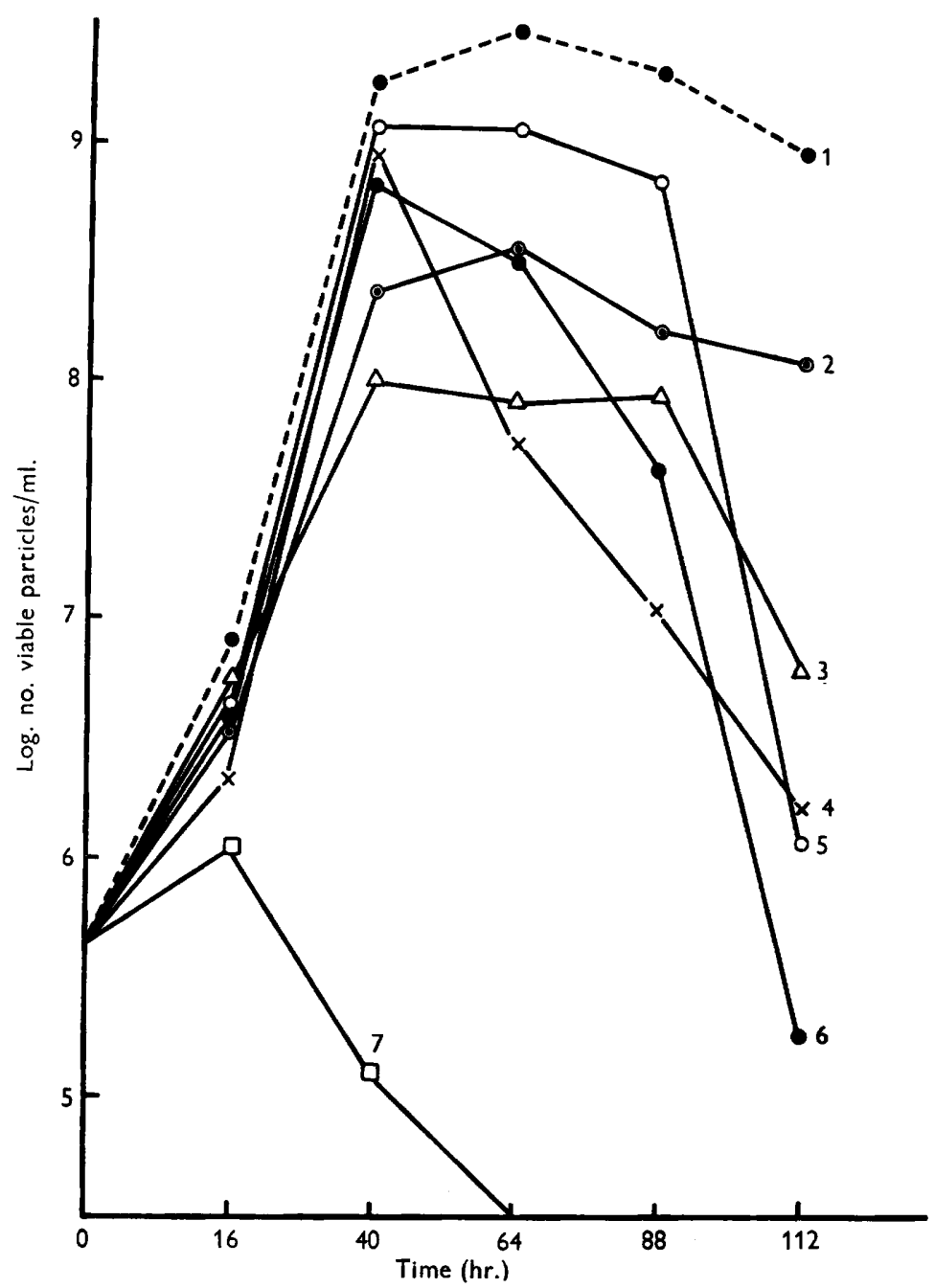

Fig. 8. Growth of Mycoplasma laidlawii in various experimental media. $1=$ Edward medium; 2 = the partially defined medium + Casamino acids $+10 \%$ (v/v) PPLO serum fraction; $3=$ minimal medium $+1 \%(w / v)$ crystallized bovine plasma albumin; $4=$ minimal medium $+1 \%(w / v)$ bovine serum albumin fraction $V ; 5=$ minimal medium $+10 \%(v / v)$ dialysed human serum; $6=$ minimal medium $+10 \%(v / v)$ whole human serum; $7=$ minimal medium $+1 \%(w / v)$ charcoal.

\section{DISCUSSION}

The minimal medium developed in the present work may not reflect the minimal growth requirements of Mycoplasma laidlawii in the strict sense; nevertheless it enabled a better analysis of the nutritional requirements of this organism than heretofore. The rate and extent of growth of $M$. laidlawii in this minimal medium exceeded that obtained in the less well-defined medium of Razin \& Knight $(1960 a)$. The demonstration of the requirements for phosphate, $\mathrm{Mg}^{++}$and $\mathrm{K}^{+}$was to be expected, as these are common growth requirements of micro-organisms (Snell, 
1951). The growth response of $M$. laidlawii to the concentration of $\mathrm{NaCl}$ (Fig. 2) conforms with the finding that Mycoplasma organisms can multiply only within very restricted tonicity values of the growth medium and require an optimal osmotic pressure of about 10 atmospheres (Rodwell, 1956; Adler \& Shifrine, 1960; Leach, 1962). Sucrose only partially replaced the $\mathrm{NaCl}$ requirement; growth in the presence of sucrose was inferior to that with equimolar concentrations of $\mathrm{NaCl}$. Similar results were obtained by Leach (1962, Table 4). Spermine, which enabled growth of the obligate halophile Achromobacter fischerii in a hypotonic $\mathrm{NaCl}$-deficient medium (Mager, 1959) did not enable growth of $M$. laidlawii when $\mathrm{NaCl}$ was omitted from our medium. The failure of spermine to protect growth of Mycoplasma in the hypotonic medium is apparently due to growth inhibitory properties of this polyamine. The antibacterial effect of spermine was most pronounced in alkaline media (Rozansky, Bachrach \& Grossowicz, 1954). This explains the marked growth inhibition of $M$. laidlawii by relatively low concentrations of spermine in the minimal medium, which has a $\mathbf{p H}$ value of $\mathbf{8 \cdot 3}$. However, spermine did inhibit lysis of $M$. laidlawii by alternate freezing and thawing (Razin \& Argaman, 1962). Thus spermine protects the fragile Mycoplasma cells from lysis, but at the same concentration inhibits their multiplication in the growth medium.

A metabolizable carbohydrate was found to be indispensable for the growth of Mycoplasma laidlawii in the minimal medium. This finding may be correlated with the inability of this Mycoplasma strain to catabolize amino acids. The carbo hydrate included in the medium therefore served both as a source of carbon and of energy. Similar findings were reported by Rodwell (1960) for Mycoplasma mycoides var. mycoides. This Mycoplasma organism also required a metabolizable carbohydrate in the medium, and its amino acid catabolism was very limited, serine and threonine being the only amino acids which were degraded. Although $M$. laidlawii was reported by Edward (1954) and Freundt (1958) to be able to ferment fructose, no significant growth was obtained when glucose in the minimal medium was replaced by fructose. However, the fermentation studies of Edward and Freundt were carried out in rich complex media.

The Casamino acids included in the partially defined medium of Razin \& Knight $(1960 a)$ were replaced by a mixture of 13 amino acids without affecting growth. Apparently not all amino acids included in this mixture were essential growth requirements; several amino acids could be omitted without decreasing the amount of growth. Methionine and threonine were required only when serum albumin was substituted for dialysed serum in the medium. This might have been due to the presence of sufficient amounts of these amino acids in the dialysed serum. Dialysed human serum, stored for long periods at $5^{\circ}$, was found to contain significant amounts of free amino acids liberated by proteolysis (Piez, Oyama, Levintow \& Eagle, 1960). We therefore stored the dialysed serum at $-10^{\circ}$ to minimize this proteolytic effect. Our findings indicate the ability of Mycoplasma laidlareii to utilize ammonium ion as a nitrogen source. The inability of this Mycoplasma to utilize nitrate for this purpose is in accordance with the findings of Kandler \& Kandler (1955) and Freundt (1958), who were unable to demonstrate nitrate reduction by $M$. laidlawii.

Rather unexpected was our complete failure to show degradation of any amino acid by suspensions of Mycoplasma laidlawii. This could hardly be attributed to inadequate experimental conditions, since arginine and glutamine were degraded 
by a culture of Mycoplasma hominis under identical conditions. It seems that amino acids are not good energy and carbon sources for any of the Mycoplasma strains tested so far. Even with Mycoplasma strains which are incapable of utilizing carbohydrates, amino acids cannot serve as the sole energy and carbon source, since amino acid metabolism of these strains is predominantly anabolic in nature (Smith, 1960).

Of the vitamins required by Mycoplasma laidlawii, nicotinic acid, riboflavin and thiamine were required also by $M$. mycoides var. mycoides (Rodwell, 1960). The requirement for folinic acid could be met by the addition of thymidine to the growth medium (Razin, 1962b). The no more than partial replacement of the nicotinic acid requirement by nicotinamide is not yet explained. The function of the serum albumin included in the minimal medium has not yet been studied in detail. The question is whether the albumin acts as a nutrient or merely as an adsorbent of growth inhibitors, such as unsaturated fatty acids (Davis \& Dubos, 1947). It seems that neutralization of toxic agents is not the sole function of the albumin since in the minimal medium it was not replaced by charcoal. Albumin might act as a carrier of essential nutrients (Eagle \& Piez, 1960) or might provide an adequate physical environment for growth of the plastic Mycoplasma organisms (Salzman, 1961).

We thank Mrs E. Friedberg and Mr M. Wormser for their valuable technical assistance. This work was supported in part by a grant from the Joint Research Fund of the Hebrew University-Hadassah Medical School.

\section{REFERENCES}

ADler, H. E. \& ShIFrine, M. (1960). Nutrition, metabolism, and pathogenicity of mycoplasmas. Annu. Rev. Microbiol. 14, 141.

Block, R. J., Durrum, E. L. \& Zweig, G. (1958). A Manual of Paper Chromatography and Paper Electrophoresis. 2nd ed. New York: Academic Press Inc.

ButLer, M. \& KNight, B. C. J. G. (1960). The survival of washed suspensions of Mycoplasma. J. gen. Microbiol. 22, 470.

Cook, R. P. (1958). Cholesterol. New York: Academic Press Inc.

Davis, B. D. \& Duros, R. J. (1947). The binding of fatty acids by serum albumin, a protective growth factor in bacteriological media. J. exp. Med. 86, 215.

EAgLe, H. \& Piez, K. A. (1960). The utilization of proteins by cultured human cells. $J$. biol. Chem. 235, 1095.

EDWARD, D. G. FF. (1954). The pleuropneumonia group of organisms: a review, together with some new observations. J. gen. Microbiol. 10, 27.

Edward, D. G. FF. \& Fitzgerald, W. A. (1951). Cholesterol in the growth of the pleuropneumonia group. J. gen. Microbiol. 5, 576 .

EDward, D. G. FF. \& Freundt, E. A. (1956). The classification and nomenclature of organisms of the pleuropneumonia group. J. gen. Microbiol. 14, 197.

Freundt, E. A. (1958). The Mycoplasmataceae (The pleuropneumonia group of organisms) Morphology, Biology and Taxonomy. Copenhagen: Munksgaard.

Gilby, A. R., Few, A. V. \& McQuillen, K. (1958). The chemical composition of the protoplast membrane of Micrococcus lysodeikticus. Biochim. biophys. Acta, 29, 21.

Giri, K. V., Radhakrishnan, A. N. \& Vaidyanathan, C. S. (1952). A simple paper chromatographic method for the study of transamination reactions. Nature, Lond. 170, 1025.

Hughes, D. E. (1951). A press for disrupting bacteria and other micro-organisms. Brit. $J$. exp. Path. 32, 97. 
KaNDLER, G. \& Kanduer, O. (1955). Ernährungs-und stoffwechselphysiologische Untersuchungen an pleuropneumonieähnlichen Organismen und der L-Phase der Bacterien. Zbl. Bakt. (Abt. II), 108, 383.

LEACH, R. H. (1962). The osmotic requirements for growth of Mycoplasma. J. gen. Microbiol. 27, 345.

Ma, T. S. \& ZuazaGa, G. (1942). Microkjeldahl determination of nitrogen. Industr. Engng Chem. (Anal.) 14, 280.

Mager, J. (1959). Spermine as a protective agent against osmotic lysis. Nature, Lond. $183,1827$.

Merrifield, R. B. \& DunN, M. S. (1950). The microbiological determination of pyrimidines with lactobacilli. J. biol. Chem. 186, 331.

Neimark, H. C. \& Pickett, M. J. (1960). Products of glucose metabolism by pleuropneumonialike organisms. Ann. N.Y. Acad. Sci. 79, 531.

Piez, K. A., Oyama, V. I., Levintow, L. \& Eagle, H. (1960). Proteolysis in stored serum and its possible significance in cell culture. Nature, Lond., 188, 59.

RAzIN, S. (1962a). Nutrition and metabolism of pleuropneumonia-like organisms. In Pleuropneumonia-like Organisms (PPLO) Mycoplasmataceae. Ed. E. Klieneberger-Nobel. London: Academic Press Inc.

RazIN, S. (1962b). Nucleic acid precursor requirements of Mycoplasma laidlazii. J. gen. Microbiol. 28, 243.

RAzIN, S. \& ARgaman, M. (1968). Lysis of Mycoplasma, bacterial protoplasts, spheroplasts and L-forms by various agents. J. gen. Microbiol. 30, 155.

Razin, S. \& KNight, B. C. J. G. (1960a). A partially defined medium for the growth of Mycoplasma. J. gen. Microbiol. 22, 492.

Razin, S. \& KnIGHT, B. C. J. G. (1960b). The effects of ribonucleic acid and deoxyribonucleic acid on the growth of Mycoplasma. J. gen. Microbiol. 22, 504.

Razin, S. \& Olrver, O. (1961). Morphogenesis of Mycoplasma and Bacterial L-form colonies. J. gen. Microbiol. 24, 225.

Rodwell, A. W. (1956). The role of serum in the nutrition of Asterococcus mycoides. Aust. J. biol. Sci. 9, 105.

RoDWELl, A. W. (1960). Nutrition and metabolism of Mycoplasma mycoides var. mycoides. Ann. N.Y. Acad. Sci. 79, 499.

Rodwell, A. W. \& Аввот, A. (1961). The function of glycerol, cholesterol and long-chain fatty acids in the nutrition of Mycoplasma mycoides. J. gen. Microbiol. 25, 201.

Rothblat, G. H. \& Smith, P. F. (1961). Nonsaponifiable lipids of representative pleuropneumonia-like organisms. J. Bact. 82, 479.

Rozansky, R., Bachrach, U. \& Grossowicz, N. (1954). Studies on the antibacterial action of spermine. J. gen. Microbiol. $10,11$.

Salzman, N. P. (1961). Animal cell cultures. Science, 133, 1559.

Smrth, P. F. (1955). Amino acid metabolism by pleuropneumonia-like organisms. I. General catabolism. J. Bact. 70, 552.

SmrTh, P. F. (1960). Amino acid metabolism of PPLO. Ann. N.Y. Acad. Sci. 79, 543.

Smith, P. F. \& LYNN, R. J. (1958). Lipid requirements for the growth of pleuropneumonialike organisms. J. Bact. 76, 264.

Smith, P. F. \& Morton, H. E. (1951). The separation and characterization of the growth factor in serum and ascitic fluid which is required by certain pleuropneumonia-like organisms. J. Bact. 61, 395.

SNELl, E. E. (1951). Bacterial nutrition-chemical factors in Bacterial Physiology, p. 214. Ed. C. H. Werkman and P. W. Wilson. New York: Academic Press Inc.

Tabor, H., Tabor, C. W. \& Rosenthal, S. M. (1961). The biochemistry of the polyamines, spermidine and spermine. Ann. Rev. Biochem. 30, 579.

TountellotTe, M. E. \& Jacobs, R. E. (1960). Physiological and serological comparisons of PPLO from various sources. Ann. N.Y. Acad. Sci. 79, 521.

Umbreit, W. W., Burris, R. H. \& Stauffer, J. F. (1957). Manometric Techniques. Minneapolis: Burgess Publishing Co. 